\title{
Use of cell phones in the transmission of preventive messages about COVID-19 to pregnant women in Yucatan, Mexico. Preliminary data
}

\section{Uso de celulares en la transmisión de mensajes preventivos sobre COVID-19 a mujeres embarazadas de Yucatán, México. Datos preliminares}

\author{
RODRÍGUEZ-ANGULO, Elsa†*, ROSADO-ALCOCER, Ligia, CABALLERO-CANUL Ricardo and \\ GÓMEZ-CASTILLO, José
}

Universidad Autónoma de Yucatán, Centro de Investigaciones Regionales “Dr. Hideyo Noguchi”. Av. Itzaes, Centro, 97000 Mérida Yucatán, México.

ID $1^{\text {st }}$ Author: Elsa, Rodríguez-Angulo / ORC ID: 0000-0001-5959-1341, Researcher ID Thomson: S-4625-2018, CVU CONACYT ID: 111408

ID $1^{\text {st }}$ Coauthor: Ligia, Rosado-Alcocer / ORC ID: 0000-0002-1806-9802, Researcher ID Thomson: ABE-2804-2020, CVU CONACYT ID: 290817

ID $2^{\text {nd }}$ Coauthor: Ricardo, Caballero-Canul / ORC ID: 0000-0002-5813-5915

ID $3^{\text {rd }}$ Coauthor: José, Gómez-Castillo / ORC ID: 0000-0001-7451-6454

DOI: $10.35429 /$ EJRG.2020.10.6.6.11

Received March 10, 2020; Accepted June 30, 2020

\begin{abstract}
Objective. Present a strategy to rescue pregnant women from the pandemic through the use of mobile technology, to explore their health status and provide preventive information to limit damage. Methodology. Descriptive, cross-sectional study. Pregnant women from two municipalities of Yucatan participated. Based on national guidelines and direct questions to a sample of pregnant women, infographics were prepared on the main warning signs and most common questions about COVID-19, respectively. The infographics were sent to each pregnant woman's cell phone. Descriptive statistics were used and tables, graphs and figures were prepared to present the results. Contribution. 330 pregnant women were identified, of which $50(15.1 \%)$ have already received infographics. The main doubts of a sample of 13 (3.9\%) pregnant women about COVID-19 were: if something can happen to their baby if they get COVID-19, 13 (100\%); if you can give COVID-19 to your baby in the hospital, 12 (92.3\%); what measures to take and how to prevent COVID$19,12(92.3 \%)$; risks in childbirth if you get COVID-19, 7 $(53.8 \%)$. It is important to continue with preventive information through digital means to improve the knowledge of pregnant women and prevent the risk of contagion. This study contributes to reduce the maternal mortality.
\end{abstract}

\section{Resumen}

Objetivo. Presentar una estrategia de rescate de embarazadas ante la pandemia a través del uso de tecnología móvil, para explorar su estado de salud y proporcionar información preventiva para limitar daños. Metodología. Estudio descriptivo, transversal. Participaron embarazadas de dos municipios de Yucatán. Basados en lineamientos nacionales y preguntas directas a una muestra de embarazadas, se elaboraron infografías sobre principales signos de alarma y preguntas más comunes sobre COVID-19, respectivamente. Las infografías fueron enviadas al celular de cada embarazada. Se utilizó estadística descriptiva y se elaboraron tablas, gráficos y figuras para presentar los resultados. Contribución. Se identificaron 330 embarazadas, de las cuales $50(15.1 \%)$ ya recibieron infografías. Las principales dudas de una muestras de 13(3.9\%) embarazadas sobre COVID-19 fueron: si le puede pasar algo a su bebé si le da COVID-19, 13 (100\%); si le puede dar COVID-19 a su bebé en el hospital, 12 ( 92.3\%); qué medidas tomar y cómo prevenir el COVID-19, 12 ( $92.3 \%$ ); riesgos en el parto si les da COVID-19, 7 ( 53.8\%). Es importante continuar con la información preventiva a través de medios digitales para mejorar los conocimientos de las embarazadas y prevenir el riesgo de contagio. Este studio contribuye a reducer la mortalidad maternal.

Teléfono celular, Embarazo, COVID-19

\footnotetext{
* Correspondence to Author (email: rangulo@correo.uady.mx)

$\dagger$ Researcher contributing first author.
} 


\section{Introduction}

Access to mobile technology has increased substantially in recent years as has access to the Internet, with the cell phone being an appropriate channel or device for the communicationpersonalization model for the purpose of transmitting health messages. (Moller, 2020; Sandberg, Spears, Nguyen, Talton, Quandt, Chen, et al; 2016) The National Institute of Statistics and Geography (INEGI), in collaboration with the Ministry of Communications and Transport (SCT) and the Federal Institute of Telecommunications (IFT), published the National Survey on the Availability and Use of Information Technologies in Homes (ENDUTIH; 2019); where it is reported that there are 80 in Mexico. 6 million Internet users, representing $70.1 \%$ of the population aged six years or more. This figure reveals an increase of 4.3 percentage points over that registered in 2018 (65.8\%); between 2017 and 2019, users in the urban area went from $71.2 \%$ to $76.6 \%$, while in the rural area the increase was from $39.2 \%$ to $47.7 \%$. The main activities of Internet users in 2019 corresponded to entertainment (91.5\%), obtaining information $(90.7 \%)$ and communicating (90.6\%). (INEGI; 2019).

For this reason, Information and Communication Technologies (ICT) is an opportunity to improve health-related processes, where the World Health Organization defines eHealth as "the cost-effective and safe use of information and communication technologies to support health and health-related fields, including health care services, health surveillance, health information and education, knowledge and research in health". (WHO, 2005) However, this concept remains controversial and several definitions have been presented.

Cell phones and other wireless devices have the potential to disrupt traditional health care delivery by allowing consumers to interact with health information, co-management conditions, and gain support for health challenges. (Brown; 2019) This transformation, known as mobile health (mHealth), is based on the near ubiquitous presence and functionality of mobile devices, which puts health promotion initiatives in the hands of consumers.
In addition, mHealth can expand equitable access to health to underserved populations (Hobson; 2019), such as the $17.27 \%$ of the population that is not entitled to health services in our country. (CONEVAL; 2015)

Due to the situation of the COVID-19 pandemic that since March of this year has confined the population at home, pregnant women in both rural and urban areas have stopped going to their prenatal control, increasing their degree of vulnerability and risk, and a solution to this problem for medical care is the use of mobile health where patients can be monitored, provide personal digital assistance and transmit preventive messages. This tool can help health services to provide care to patients remotely, save the cost of travel for patients and their families, and assist clinics in providing personalized care to reduce the patient load. (Cusack; 2008) (Ryu; 2012).

According to data published by INEGI 2010, the state of Yucatan has 1,955,577 inhabitants, of which $79.48 \%$ (1,554,422 people) have a cell phone and 1,400,366 have internet. (INEGI; 2019). Likewise, in this entity there are Mayan communities where there are high-risk pregnancies that put the life of the mother and the fetus at risk (Angulo, Cervantes, Pech y Vergara, 2007), and that the use of mobile health can help to provide information and timely attention to pregnant women. For this reason, the objective of the study is to present a strategy for rescuing pregnant women from the pandemic through the use of mobile technology, to explore their health status, and to provide preventive information to limit damage.

\section{Material and Methods}

Descriptive, cross-sectional study. Pregnant women from two municipalities in the rural area of Yucatan participated. Based on national guidelines and direct questions to a sample of pregnant women, infographics were prepared on the main warning signs and most common questions about COVID-19, respectively; as well as flowcharts of what to do if the pregnant woman becomes ill. The infographs were sent to each pregnant woman's cell phone. Descriptive statistics were used and tables, graphs and figures were elaborated to present the results. 
Through simple random sampling (Statcalc Epi Info Program), with a confidence level of $80 \%$ and an expected proportion of $98 \%$, the sample size was calculated with confidence limits of $5 \%$, and a sample of 11 pregnant women to be surveyed was obtained. Taking into account a $15 \%$ loss of information, the sample was increased by $15 \%$, with a total of 13 pregnant women. With prior informed consent, and keeping a healthy distance, use of mask and mouthpiece, pregnant women from the outpatient clinic were invited to answer a questionnaire with questions about what they would like to know about COVID-19, about their knowledge of the warning signs, care of the pregnant woman and how to prevent the spread of the disease; each participant was asked for her cell phone number and the number of other pregnant women registered was obtained from their pregnancy control card.

Three doctors and a community nurse participated as surveyors, who were trained for this activity. The norms and guidelines established at a national level on Pregnancy and COVID-19 (Government of Mexico; 2020) were analyzed and based on the participants' answers, materials were elaborated to disseminate the type of infographics and videos, preserving cultural features in the language and drawings. Before the distribution of the infographics, a presentation infographic was designed and a notice was given that they would receive digital material in their cell phones and to have the authorization to use their number to make the shipments.

\section{Results}

330 pregnant women were identified in the databases of the participating Health Centers. The age range was 14-40 years, with a mean age of 25.7 years. The main questions about COVID-19, from a sample of 13 (3.9\%) pregnant women were: if something can happen to their baby if they get COVID-19, $13(100 \%)$; if they can give COVID-19 to their baby in the hospital, 12 (92.3\%); what measures to take and how to prevent COVID-19, 12 (92.3\%); risks in labor if they get COVID-19, 7 (53.8\%) (Table 1). Regarding knowledge of the warning signs for the disease, $13(100.0 \%)$ pregnant women responded at least, the best known being cough in $11(84.6 \%)$ of them (Chart 1).
Regarding where to go if they get sick, 9 $(69.2 \%)$ responded that they should go to the health center and $4(31.8 \%)$ to the community hospital. Regarding the care of pregnant women suspected or positive for COVID-19, most $(69.2 \%)$ reported that they should stay home and isolate themselves (Graph 2); and about how to prevent infection, using mouth guards, hand washing and use of antibacterial gel were the main responses, in $8(61.5 \%), 7(53.85)$ and $6(46.1 \%)$ of pregnant women, respectively (Table 3). Fifty infographs were distributed via cell phone to the mothers (Fig.1).

\begin{tabular}{|c|c|c|c|}
\hline Question & Answers & $\begin{array}{c}\text { Number } \\
n=13\end{array}$ & $\%$ \\
\hline \multirow{4}{*}{$\begin{array}{l}\text { What would you } \\
\text { like to know about } \\
\text { COVID-19? }\end{array}$} & $\begin{array}{l}\text { If something } \\
\text { can happen to } \\
\text { my baby }\end{array}$ & 13 & 100 \\
\hline & $\begin{array}{l}\text { If you can give } \\
\text { my baby } \\
\text { Covid in the } \\
\text { hospital }\end{array}$ & 12 & 92.3 \\
\hline & $\begin{array}{l}\text { What to do } \\
\text { and how to } \\
\text { prevent } \\
\text { Covid-19 }\end{array}$ & 12 & 92.3 \\
\hline & $\begin{array}{l}\text { Risks in } \\
\text { childbirth if I } \\
\text { get covid-19 }\end{array}$ & 7 & 53.8 \\
\hline \multirow{5}{*}{$\begin{array}{l}\text { What care should a } \\
\text { pregnant woman } \\
\text { with a suspected or } \\
\text { positive COVID- } \\
19 \text { have? }\end{array}$} & $\begin{array}{l}\text { Staying home, } \\
\text { isolation }\end{array}$ & 9 & 69.2 \\
\hline & Does not know & 4 & 30.7 \\
\hline & $\begin{array}{l}\text { Go to Health } \\
\text { Center }\end{array}$ & 2 & 15.4 \\
\hline & $\begin{array}{l}\text { Hand } \\
\text { washing, } \\
\text { frequent } \\
\text { bathing }\end{array}$ & 1 & 7.7 \\
\hline & $\begin{array}{l}\text { Do not self- } \\
\text { medicate }\end{array}$ & 1 & 7.7 \\
\hline
\end{tabular}

Table 1 Main doubts of pregnant women regarding COVID-19. $n=13$

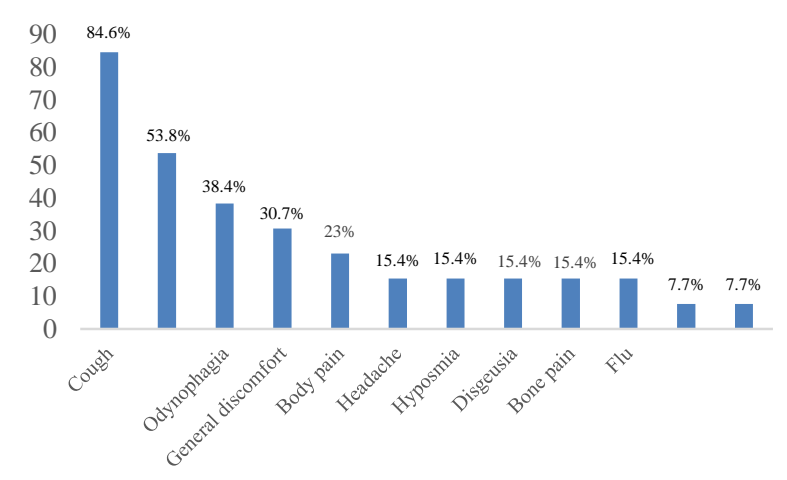

Graphic 1 Main signs and symptoms of COVID-19 known by pregnant women. $\mathrm{n}=13$ 


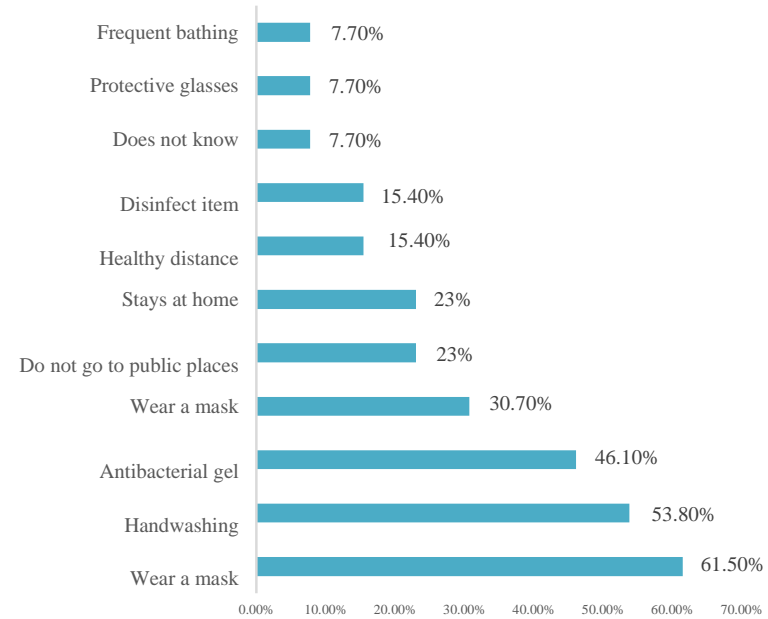

Graphic 2 Main responses of pregnant women to prevent the spread of VIDOC-19. $n=13$

\section{EMBARAZO Y COVID 19}

\section{SI ME ENFERMO ¿QUÉ DEBO HACER?}
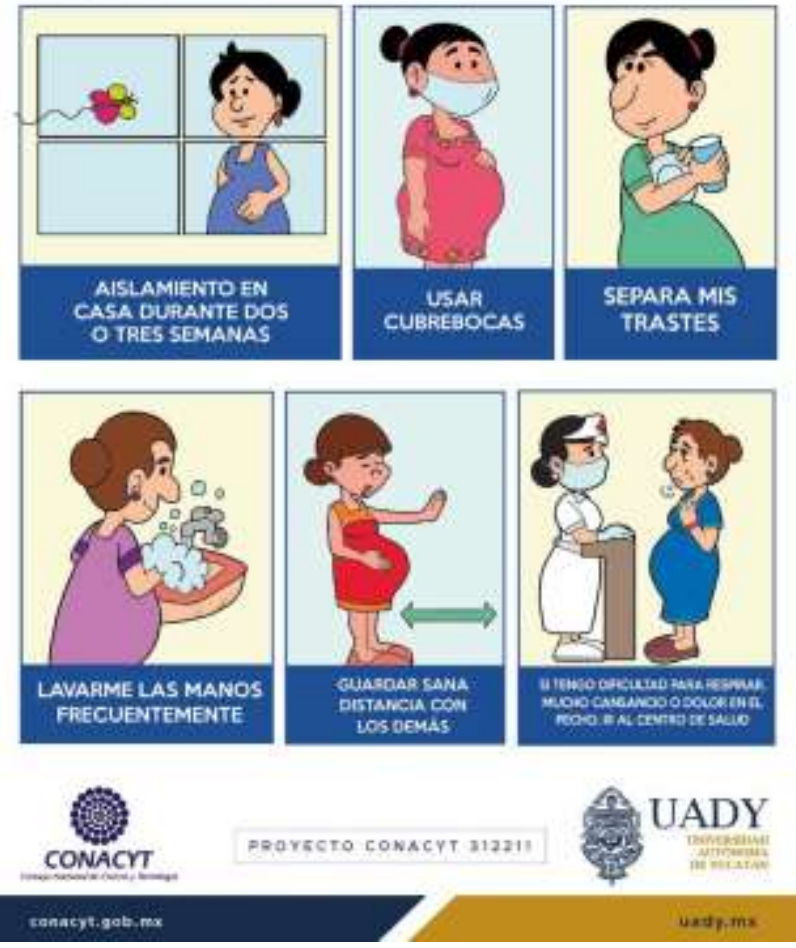

Figure 1 Infographics

\section{Acknowledgements}

To the National Council of Science and Technology of Mexico (CONACyT) for funding this study.

\section{Conclusions}

The Coronavirus pandemic that produces the COVID-19 disease produced a change in behavior in people around the world, which implied adapting to new ways of acting and proceeding in the face of the demands and restrictions that the new way of life implies in communities. (Abuabara, 2020; Morgante, Canal, Ojeda, Frávega, Blanco, Guzzo et al. 2020). There was also a need to review and update the Clinical Practice Guidelines for the care of severe cases (COVID-19, 2020). Maintaining a healthy distance, staying at home as long as possible and only leaving it for essentials, with the use of face masks and eye protection and frequent hand washing and use of antibacterial gel, are sanitary measures to follow and that day by day they must be present in our mind so as not to relax care and avoid contagion. In this study, the main questions and doubts faced by the pandemic were obtained, one of the vulnerable groups such as pregnant women;

Some are the concern of knowing what will happen to them if during pregnancy they get sick with COVID-19, what will happen to their baby and if it could be infected in the hospital at birth. It was also observed that the signs and symptoms of the disease are known to the population; This may be due to the fact that the information has been and is still widely disseminated by the mass media, to which the majority have access. Although there are studies that report that cough in pregnant women occurs in $57.1 \%$ of cases, (Castro; 2020) the women in our study recognized this sign as the main manifestation in a higher percentage $(84.6 \%)$.

Also on the care necessary to prevent contagion are in the minds of pregnant women, especially the use of face masks $(61.5 \%)$, which although at the beginning of the epidemic in Mexico its use as a protector of the SARS-COV2 virus was controversial, currently there is evidence supporting its use as a preventive measure (Esposito; 2020), but efforts must be redoubled and its use still insisted on in this population. We do not know how the infographics distributed via cell phone will impact and if they will help pregnant women to increase their knowledge of the disease, what to do if they get sick and how to prevent infections. 
This will be a challenge that we will have to face in subsequent studies to evaluate the impact of the use of technology in actions to protect the health of pregnant women against COVID-19. In other countries, the attention of the health authorities towards helping and protecting this vulnerable group has become evident, with the implementation of plans and programs that meet the local needs of pregnant women during pregnancy, childbirth and the puerperium and those of the newborn. born, faced with contingency (Changizi; 2020, Claudio; 2020, Bombini; 2020).

\section{References}

Abuabara, Y. C. (2020). Ataque al personal de la salud durante la pandemia de Covid-19 en Latinoamérica. Acta Médica Colombiana, 45(3).

Angulo, E. R., Cervantes, L. M., Pech, G. A., \& Vergara, W. M. (2007). Características médicosociales de las muertes maternas en una comunidad maya de Yucatán, México. Ginecol Obstet Mex, 75, 79-85.

Bombini, G. (2020). Tensiones en la Política Penal Postpandemia COVID-19:¿ Hacia un sistema penal más racional o más punitivista?. Nueva Crítica Penal, 2(3), 119-136.

Brown, E. L., Ruggiano, N., Li, J., Clarke, P. J., Kay, E. S., \& Hristidis, V. (2019). SmartphoneBased Health Technologies for Dementia Care: Opportunities, Challenges, and Current Practices. Journal of applied gerontology : the official journal of the Southern Gerontological Society, 38(1), 73-91.

Castro, P., Matos, A. P., Werner, H., Lopes, F. P., Tonni, G., \& Araujo Júnior, E. (2020). Covid19 and Pregnancy: An Overview. Covid-19 e gravidez: Uma visão geral. Revista brasileira de ginecologia e obstetricia : revista da Federacao Brasileira das Sociedades de Ginecologia e Obstetricia, 42(7), 420-426. https://doi.org/10.1055/s-0040-1713408

Claudio, E., Donahue, J., Niles, P. M., Pirsch, A., Ramos, P., Neely, I., Conceiçaõ, R., Thomas, M. P., St Vil, T., \& Kaplan, D. (2020). Mobilizing a Public Health Response: Supporting the Perinatal Needs of New Yorkers During the COVID-19 Pandemic. Maternal and child health journal, 24(9), 1083-1088. https://doi.org/10.1007/s10995-020-02984-6
COVID, E. G. D. T. M. (2020). Guía COVID-19 para la atención del paciente crítico con infección por SARS-CoV-2 Colegio Mexicano de Medicina Crítica. Medicina Crítica,34(1), 742.

Cusack, C. M., Pan, E., Hook, J. M., Vincent, A., Kaelber, D. C., \& Middleton, B. (2008). The value proposition in the widespread use of telehealth. Journal of telemedicine and telecare, 14(4), 167-168. https://doi.org/10.1258/jtt.2007.007043

Changizi, N., Raeisi, A., Barekati, H., Abibolahi, A. (2020). Provision of critical mternity care during the coronavirus disease 2019 (COVID19) Pandemic in the Islamic Republic of Iran. Archives of the Iranian Medicine. 23(8):557-560 https://doi.org/10.34172/aim.2020.59

Esposito, S., Principi, N., Chin, L., Migliori, G. (2020). Universal use of face masks for success against COVID-19; evidence and implications for prevention and pólices. European Respiratory Journal, 55:2001260, https://doi.org/10.1183/13993003.01260-2020

Gobierno de México. (2020). Lineamiento para la prevención y mitigación de COVID-19 en la atención del embarazo, parto, puerperio y de la persona recién nacida. 13 de noviembre 2020, de Gobierno de México Sitio web: https://coronavirus.gob.mx/wpcontent/uploads/2020/07/Lineamientos_Preven cion_COVID19_Embarazos_V2.pdf

Hobson, G. R., Caffery, L. J., Neuhaus, M., \& Langbecker, D. H. (2019). Mobile Health for First Nations Populations: Systematic Review. JMIR mHealth and uHealth, 7(10), e14877. https://doi.org/10.2196/14877

Instituto Nacional de Estadística y Geografía (INEGI), Secretaría de Comunicaciones y Transportes (SCT), Instituto Federal de Telecomunicaciones (IFT). (2019). Encuesta Nacional sobre Disponibilidad y Uso de Tecnologías de la Información en los Hogares (ENDUTIH). 13 noviembre 2020, de INEGI Sitio web: https://www.inegi.org.mx/contenidos/saladepre nsa/boletines/2020/OtrTemEcon/ENDUTIH_20 19.pdf 
Moller, S. (2020). Intervenciones sociosanitarias y uso de las tecnologías de la industria 4.0 para enfrentar la enfermedad por coronavirus (COVID-19) en América Latina y el Caribe.

Morgante, M. G., Canal, M. E., Ojea, O. A., Frávega, A., Blanco, M. L., Guzzo, A., ... \& Mariani, L. (2020). Aportes de la Mesa de Trabajo de Personas Mayores de la Universidad Nacional de La Plata en el contexto de la pandemia de COVID-19.

Ryu S. (2012). Reseña del libro: mHealth: New Horizons for Health through Mobile Technologies: Based on the Findings of the Second Global Survey on eHealth (Global Observatory for eHealth Series, Volume 3). Investigación en informática sanitaria , 18 (3), 231233. https://doi.org/10.4258/hir.2012.18.3.231

Sandberg, J. C., Spears Johnson, C. R., Nguyen, H. T., Talton, J. W., Quandt, S. A., Chen, H., Summers, P., \& Arcury, T. A. (2016). Mobile and Traditional Modes of Communication Among Male Latino Farmworkers: Implications for Health Communication and Dissemination. Journal of immigrant and minority health, 18(3), 522-531. https://doi.org/10.1007/s10903-015-0299-5

World Health Organization. WHA58.28 eHealth. En: Fifty-eighth World Health Assembly (WHA58/2005/REC/1). Ginebra, Suiza: World Health Organization; 2005. 